\title{
SUPERKAPASITOR SEBAGAI PIRANTI PENYIMPAN ENERGI LISTRIK MASA DEPAN
}

\author{
Oleh: \\ Agus Riyanto
}

\begin{abstract}
Abstrak
Superkapasitor merupakan teknologi baru yang dikembangkan dari kapasitor konvensional yang dikembangkan untuk penyimpan energi yang modern. Kapasitor ini memanfaatkan permukaan elektroda yang luas dan bahan dielektrik yang tipis untuk mencapai nilai kapasitansi yang jauh lebih besar daripada kapasitor konvensional. Hal ini memungkinkan superkapasitor akan memiliki rapat energi yang jauh lebih besar dibanding dengan kapasitor konvensional dan memiliki rapat daya jauh lebih besar daripada baterai. Sehingga, superkapasitor akan menjadi solusi yang sangat baik sebagai piranti penyimpan energi.

Keyword: superkapsitor, kapasitansi, rapat energi, dan rapat daya
\end{abstract}

\section{Pendahuluan}

Dalam kehidupan yang serba modern saat ini, energi listrik menjadi kebutuhan utama yang tidak dapat dielakkan. Bebagai teknologi yang ada saat ini, sebagaian besar membutuhkan piranti penimpan energi listrik. Sebagai contohnya telepon selular dan laptop membutuhkan baterai sebagai piranti penyimpan energi. Namun, kendalanya baterai memiliki rapat daya yang cukup kecil disamping itu juga dibutuhkan waktu yang cukup lama untuk mengecas (penimpanan) enegi listrik kedalam piranti tersebut. Oleh sebab itu, dibutuhkan teknologi yang memiliki rapar energi dan rapat daya yang lebih besar serta waktu pengecasan yang lebih singkat untuk memenuhi kebutuhan teknologi dimasa mendatang. Sejauh ini telah terdapat minat yang besar dikalangan para peneliti untuk mengembangkan dan menyempurnakan perangkat penyimpanan energi yang lebih efisien. Salah satu perangkat tersebut ialah superkapasitor. Superkapasitor, juga dikenal sebagai ultrakapasitor atau kapasitor elektrokimia, memanfaatkan permukaan elektroda dan larutan elektrolit dielektrik tipis untuk mencapai kapasitansi beberapa kali lipat lebih besar dibandingkan kapasitor konvensional [1-5]. 
Kapasitor konvensional terdiri

dari dua elektroda yang dipisahkan oleh bahan dielektrik. Saat tegangan listrik diberikan pada kapasitor, muatan berlawanan (berbeda) akan terakumulasi pada setiap permukaan elektroda. Muatan-muatan tersebut akan tetap terpisah oleh bahan dielektrik yang mengisi ruang antarpelat kapasitor, sehingga menghasilkan medan listrik yang menyebabkan kapasitor dapat menyimpan energi.

$$
\text { Kapasitansi didefinisikan }
$$

sebagai perbandingan antara muatan yang tersimpan dalam kapasitor $(Q)$ dengan potensial listrik $(V)$ yang diberikan.

$$
C=\frac{Q}{V}
$$

Untuk kapasitor konvensional
berbanding lurus dengan luas
permukaan pada setiap permukaaan dan
banding terbalik dengan jarak antar
muatan

$$
C=\varepsilon_{0} \varepsilon_{r} \frac{A}{D}
$$

Dengan $\varepsilon_{0}$ ialah konstanta dielektrik atau permitivitas ruang vakum dan $\varepsilon_{r}$ ialah konstanta dielektrik bahan isolasi antara elektroda. Untuk mengukur kerapatan dapat dihitung sebagai jumlah per satuan massa atau per unit volume. Energi $E$ yang tersimpan dalam kapasitor berbanding lurus dengan kapasitansi:

$E=\frac{1}{2} C V^{2}$

Secara umum, daya $P$ adalah energi yang dikeluarkan per satuan waktu. Untuk menentukan daya kapasitor, kita harus mempertimbangkan bahwa kapasitor umumnya direpresentasikan sebagai sirkuit seri dengan hambatan eksternal $R$, seperti yang ditunjukkan pada Gambar 1. 


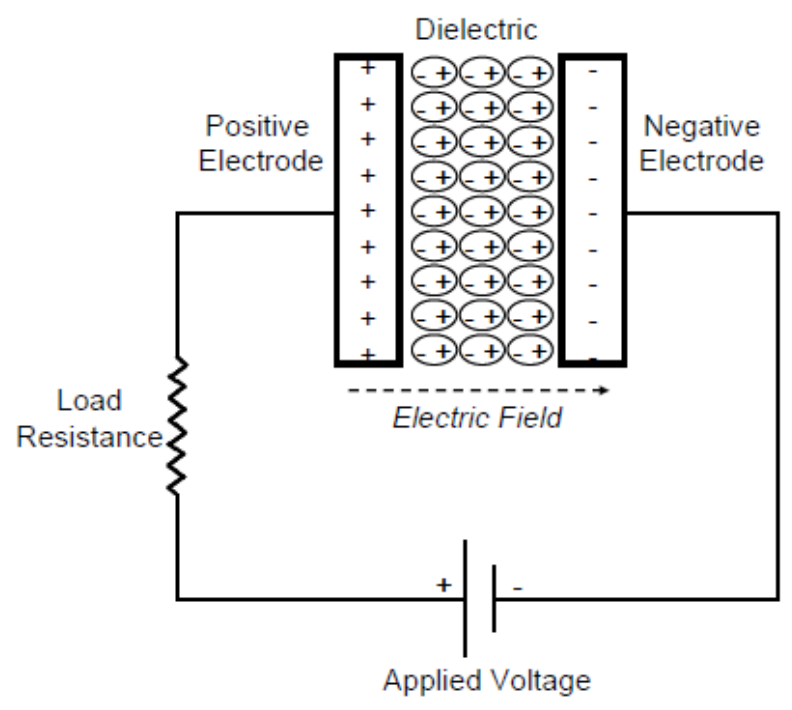

Gambar 1. Kapasitor konvensional

Komponen internal kapasitor (misalnya kolektor, elektroda, dan bahan dielektrik) juga berkontribusi terhadap resistansi (hambatan), yang diukur secara akumulatif dengan kuantitas yang dikenal sebagai equivalent series resistance (ESR). Tegangan selama tidak dalam proses pengisian ditentukan oleh resistensi ini. Ketika diukur pada impedansi penyesuaian (R=ESR) [1-2, 5], yang daya maksimum untuk sebuah kapasitor diberikan oleh:

$P_{\max }=\frac{V^{2}}{4 \times E S R}$
Hubungan ini menunjukkan bagaimana ESR dapat membatasi daya maksimum sebuah kapasitor. Kapasitor konvensional memiliki kerapatan daya yang relatif tinggi, namun relatif rendah kepadatan energi bila dibandingkan dengan baterai elektrokimia dan baterai. Baterai dapat menyimpan lebih banyak energi dibanding kapasitor, tetapi tidak dapat dilakukan pengisian (pengecasan) secara cepat, yang berarti bahwa kerapatan daya rendah. Disisi lain, kapasitor menyimpan energi per satuan massa atau volume relatif lebih kecil, tapi energi listrik dapat disimpan dengan cepat untuk menghasilkan banyak daya, sehingga kerapatan dayanya tinggi relatif lebih tinggi. 
Superkapakitor mengikuti kapasitor konvensional, supercapacitors prinsip-prinsip dasar yang sama seperti juga dapat mencapai kepadatan daya konvensional kapasitor. Namun, pada yang sebanding. superkapasitor luas area permukaan Selain itu, supercapacitors memiliki elektroda $A$ dibuat lebih besar dan beberapa keunggulan dibandingkan ketebalan bahan dielektrik dibuat jauh baterai elektrokimia dan baterai, yaitu lebih tipis sehingga menurunkan jarak kerapatan daya lebih tinggi, pengisian $D$ antara elektroda. Dengan demikian, lebih pendek, dan siklus hidup dan menurut persamaan 2 dan 3 , hal ini dapat menyebabkan peningkatan baik kapasitansi dan energi pada kapasitor. umur simpan yang lebih lama [1-3]. Gambar 2 memberikan diagram skematik superkapasitor.

$$
\text { Selain itu, dengan }
$$

mempertahankan karakteristik low ESR

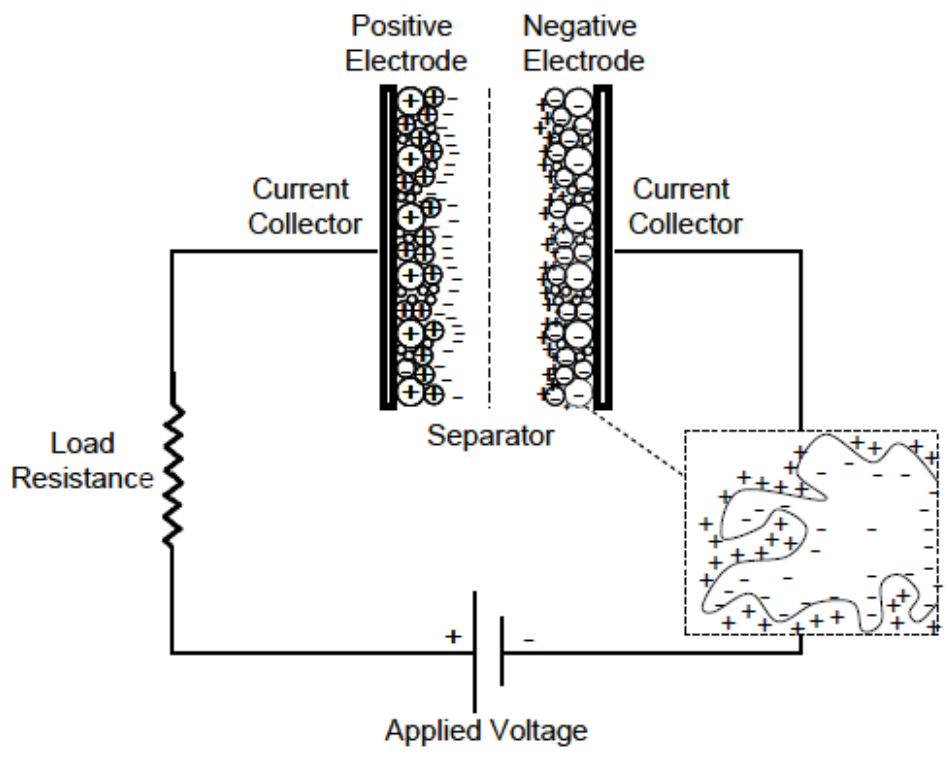

Gambar 2. Skema Superkapasitor 


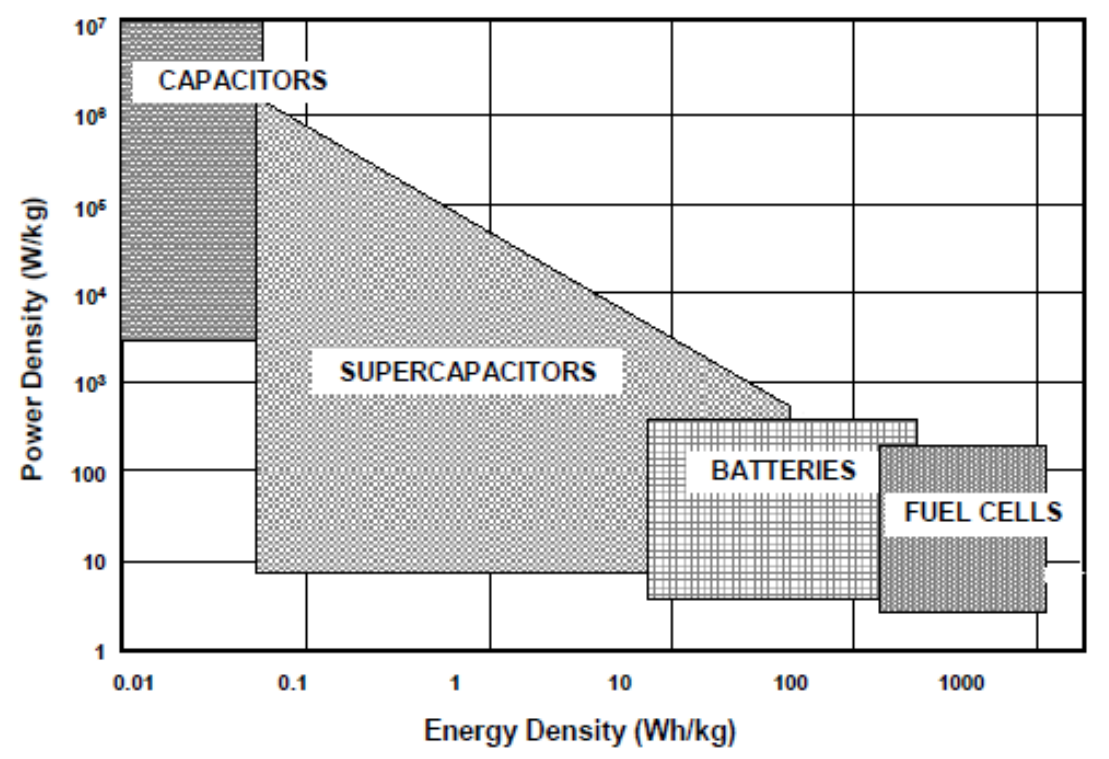

Gambar 3. Performa Superkapasitor

Performa superkapasitor ditunjukkan pada Gambar 3, grafik tersebut disebut dengan "Ragone plot." Grafik tersebut menyajikan rapat daya berbagai perangkat penyimpanan energi dibandingkan dengan rapat energinya. Pada Gambar 3, terlihat bahwa supercapakitor menempati daerah antara kapasitor konvensional dan baterai [3]. Meskipun, kapasitansi memiliki yang lebih besar daripada kapasitor konvensional, supercapacitors belum mencapai rapat energi yang dimiliki baterai dan fuel cell.

$$
\text { Dalam makalah ini }
$$
dideskripsikan taksonomi dan prinsip kerja superkapasitor sehingga dapat memberikan gambaran nyata mengenai superkapasitor yang telah dikembangkan oleh para peneliti.

2. Taksonomi Superkapakitor

Berdasarkan perkembangan riset saat ini, superkapakitor dapat dibagi menjadi tiga kelas utama yaitu: kapasitor elektrokimia double-layer, pseudokapasitor, dan kapasitor hibrid. Setiap kelas memiliki mekanisme yang unik dalam menyimpan muatan, yaitu dengan mekanisme non-Faradaic, Faradaic, dan kombinasi dari dua. Proses Faradaic terjadi sebagaimana reaksi oksidasi-reduksi yang melibatkan transfer muatan antara elektroda dan elektrolit. Sebaliknya, mekanisme nonFaradaic tidak menggunakan 
mekanisme kimia. Muatan didistribusikan pada permukaan oleh proses fisik yang tidak melibatkan terbentuk atau terputusnya ikatan kimia.

\subsection{Electrochemical double-layer} capacitors (EDLCs)

Electrochemical double-layer capacitors (EDLCs) tersusun atas dua elektroda berbasis karbon, elektrolit, dan pemisah. Gambar 2 menunjukkan skema EDLCs. Sebagaimana kapasitor konvensional, EDLCs menyimpan muatan secara elektrostatis (nonFaradaic) dan tidak ada transfer muatan antara elektroda dan elektrolit.

EDLCs memanfaatkan muatan elektrokimia double-layer untuk menyimpan energi. Bila tegangan diterapkan, muatan terakumulasi pada permukaan elektroda. Ion-ion dalam larutan elektrolit mengalir melalui separator ke dalam pori-pori elektroda muatan pada elektroda yang berlawanan muatan. Namun, elektroda direkayasa untuk mencegah rekombinasi ion. Sehingga, muatan doble layer dihasilkan di setiap elektroda elektroda. Double-layer tersebut, tercipta seiring dengan peningkatan luas permukaan dan penurunan jarak antara elektroda, hal memungkinkan EDLCs untuk mencapai energi yang lebih tinggi kepadatan dibandingkan kapasitor konvensional [1-3].

Karena tidak ada transfer muatan antara elektrolit dan elektroda, tidak terdapat bahan kimia atau komposisi muatan yang terkait dengan proses non-Faradaic. Untuk alasan ini, muatan yang tersimpan di EDLCs sangat reversibel yang memungkinkan muatan tersebut dapat mencapai kestabilan siklus. EDLCs umumnya beroperasi dengan performa yang stabil dengan banyak siklus charge-discharge, kadang-kadang sebanyak $10^{6}$ siklus. Di sisi lain, baterai elektrokimia umumnya terbatas pada hanya sekitar $10^{3}$ siklus. Karena stabilitas siklusnya, EDLCs sangat cocok untuk aplikasi pada wilayah yang sulit dijangkau seperti laut, pegunungan, dan laut dalam [1-3, 6].

Performa sebuah EDLCs dapat disesuaikan dengan mengubah sifat elektrolit. Sebuah EDLCs dapat memanfaatkan larutan atau elektrolit organik.

Elektrolit seperti $\mathrm{H}_{2} \mathrm{SO}_{4}$ dan $\mathrm{KOH}$, umumnya memiliki ESR yang lebih rendah dan memiliki ukuran pori lebih kecil dibandingkan dengan elektrolit organik, seperti asetonitril. Namun, 
larutan elektrolit juga memiliki tegangan breakdown yang lebih rendah. Oleh karena itu, pemilihan antara larutan elektrolit atau organik, harus mempertimbangkan kapasitansi, ESR, dan tegangan $[1-3,6]$.

\subsection{Psudokapasitor}

Berbeda dengan EDLCs yang menyimpan muatan secara elektrostatis, psudokapasitor menyimpan muatan secara Faradaic melalui transfer muatan antara elektroda dan elektrolit. Hal tersebut terjadi melalui electrosorption, reaksi reduksi-oksidasi, dan proses interkalasi [1,7-8]. Proses Faradaic ini memugkinkan psudokapasitor mencapai kapasitansi yang lebih besar dan rapat energi yang lebih besar dari EDLCs [910]. Terdapat dua material elektroda yang digunakan untuk menyimpan muatan dalam psudokapasitor yaitu polimer konduktif dan logam oksida (metal oxide).

\subsection{Kapasitor Hibrid}

\section{Daftar Pustaka}

Conway,

B.

E.

(1999).

Electrochemical

Supercapacitors : Scientific

Fundamentals

and
Kapasitor hibrid mencoba untuk mengeksploitasi manfaat dan mengidentifikasi kerugian EDLCs dan psudokapasitor unntuk menciptakan performa superkapasitor yang lebih baik. Kapasitor ini memanfaatkan proses Faradaic dan non-Faradaic untuk menyimpan energi. Kapasitor hibrid dapat mencapai dapat mencapai rapat energi dan daya lebih besar dibandingkan EDLCs tanpa mengurangi stabilitas siklusnya. Saat ini riset telah difokuskan pada tiga jenis kapasitor hibrid yaitu kapasitor dengan elektroda komposit, asimetri, dan tipe baterai.

\section{Kesimpulan}

Superkapasitor memiliki pontesi yang besar untuk dikembangkan menjadi piranti penyimpanan energi listik karena memiliki rapat energi dan rapat daya yang besar, waktu pengecasan yang lebih pendek, serta memiliki siklus hidup yang lebih panjang daripada baterai.

Technological Applications. New York, Kluwer-Plenum.

Burke, A. (2000). "Ultracapacitors: why, how, and where is the 
technology." Journal of Power

Sources 91(1): 37-50.

Kotz, R. and M. Carlen (2000).

"Principles and applications of electrochemical capacitors." Electrochimica Acta 45(1516): 2483-2498.

Aricò, A. S., P. Bruce, et al. (2005).

"Nanostructured materials for advanced energy conversion and storage devices." Nature Materials(4): 366-377.

Chu, A. and P. Braatz (2002). "Comparison of commercial supercapacitors and

Kim, I. H. and K. B. Kim (2001). "Ruthenium oxide thin film electrodes for supercapacitors."

Electrochemical and Solid State Letters 4(5): A62-A64.

Mastragostino, M., C. Arbizzani, et al. (2001). "Polymer-based highpower lithium-ion batteries for power-assist applications in hybrid electric vehicles I. Initial characterization." Journal of Power Sources 112(1): 236246.

Amatucci, G. G. (2006). Private communication.

Conway, B. E., V. Birss, et al. (1997). "The role and utilization of pseudocapacitance for energy storage by supercapacitors." Journal of Power Sources 66(12): 1-14.

supercapacitors." Journal of Power Sources 97-8: 812-815.

Ryu, K. S., K. M. Kim, et al. (2002). "Symmetric redox supercapacitor with conducting polyaniline electrodes." Journal of Power Sources 103(2): 305-309 